Supporting Information for:

\title{
Improving $\beta$-galactosidase catalyzed transglycosylation yields by cross-linked layer-by-layer enzyme immobilization
}

Masih Karimi Alavijeh a,b, Anne S. Meyer c, Sally L. Gras a,b, Sandra E. Kentish a,*

a Department of Chemical Engineering, The University of Melbourne, Parkville, VIC 3010, Australia

b The Bio21 Molecular Science and Biotechnology Institute, The University of Melbourne, Parkville, Vic 3010, Australia

c Protein Chemistry and Enzyme Technology Division, Department of Biotechnology and Biomedicine, Technical University of Denmark, DTU, DK-2800, Kgs Lyngby, Denmark

*Corresponding author:

E-mail: sandraek@unimelb.edu.au (Sandra Kentish).

This supplementary material includes 22 pages, 3 Tables and 4 Figures. 


\section{Table of Contents}

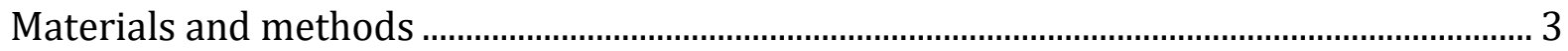

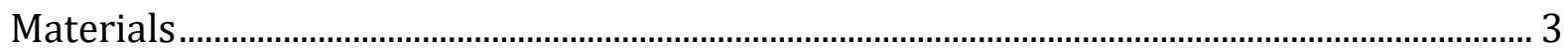

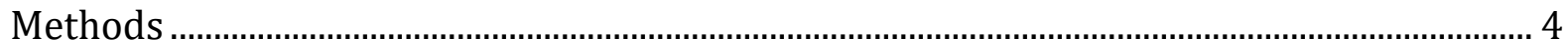

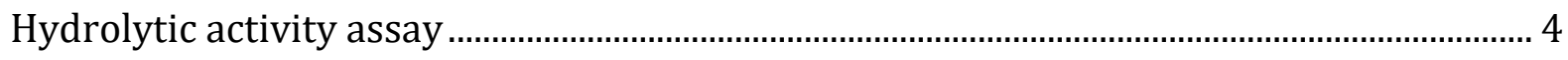

Biotransformation of lactose via transgalactosylation reaction............................................... 4

Determination of immobilization efficiency, activity retention and performance index .. 6

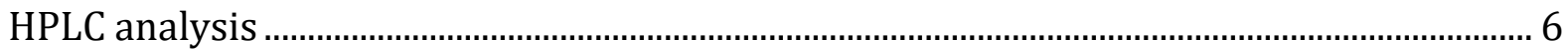

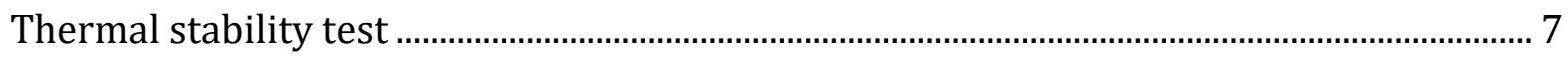

Characterization methods: ATR-FTIR analysis, zeta potential measurement, thermogravimetric analysis and digital microscopy................................................................. 8

Determination of reusability of immobilized $\beta$-galactosidase ............................................... 8

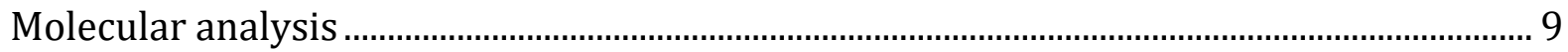

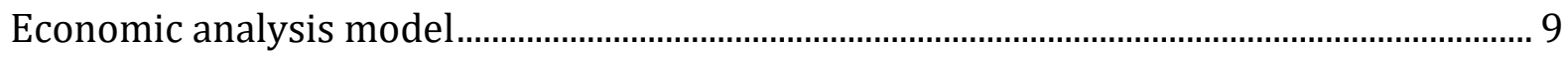

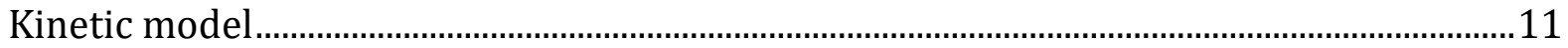

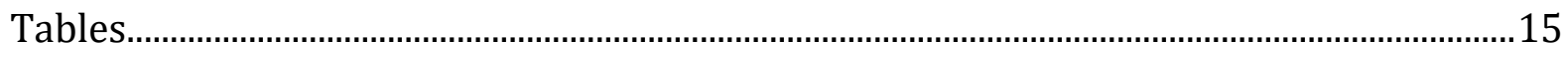

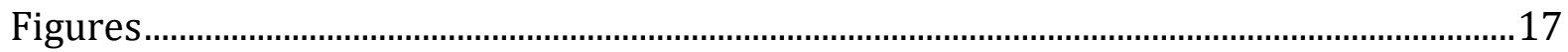

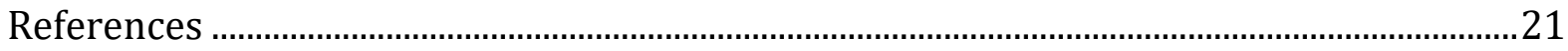




\section{Materials and methods}

\section{Materials}

Galactose, glucose, citric acid monohydrate, hydrochloric acid solution (1M), tris(hydroxymethyl)methylamine (Tris), chloroform, methanol, calcium chloride dihydrate $\left(\mathrm{CaCl}_{2} \cdot 2 \mathrm{H}_{2} \mathrm{O}\right)$, magnesium chloride hexahydrate $\left(\mathrm{MgCl}_{2} \cdot 6 \mathrm{H}_{2} \mathrm{O}\right)$, disodium hydrogen orthophosphate (anhydrous powder) and sodium carbonate anhydrous were purchased from Chem-Supply (Gillman, Australia). Lactose and $p$-nitrophenol (pNP) were purchased from Thermo Fisher Scientific (Scoresby, Australia). $p$-nitrophenyl $\beta$-galactopyranoside (pNP- $\beta$-Gal), $\quad$ N-acetylallolactosamine $\quad$ (Gal- $\beta(1,6)-G l c N A c ; \quad$ Allo-LacNAc), polystyrenesulfonate (PSS; $70 \mathrm{kDa}$ ) and polyallylaminehydrochloride (PAH; $10 \mathrm{kDa}$ ) were supplied by Sigma Aldrich (St. Louis, MO, USA). N-acetylglucosamine (GlcNAc) was purchased from Carbosynth (Berkshire, UK). N-acetyllactosamine (Gal- $\beta(1,4)-G l c N A c ;$ LacNAc) was purchased from Sapphire Bioscience Pty. Ltd (NSW, Australia). Glutaraldehyde (25 wt\% aqueous solution) was obtained from Ajax Finechem (Taren Point, NSW, Australia). Commercial silica particles SIPERNAT ${ }^{\circledR} 50 \mathrm{~S}$ with $500 \mathrm{~m}^{2} / \mathrm{g}$ specific surface area and an average diameter of 18 micron were kindly provided by Evonik Resource Efficiency GmbH (Essen, Germany). Acetonitrile HPLC grade was obtained from Merck (Darmstadt, Germany). A commercial $\beta$-galactosidase preparation derived from Bacillus circulans (Lactazyme-B) was kindly donated by GenoFocus (Daejeon, South Korea). Ultrapure water (Millipore Elix, resistivity of $18.2 \mathrm{M} \Omega \cdot \mathrm{cm}$ at $25^{\circ} \mathrm{C}$ ) was used for preparation of solutions and cleaning. All chemicals and reagents were of analytical grade and were used as obtained unless otherwise specified. 


\section{Methods}

\section{Hydrolytic activity assay}

The $\beta$-galactosidase hydrolytic activity was assayed by measuring the amount of $\mathrm{p}$ nitrophenol (pNP) liberated from the hydrolysis of p-nitrophenyl $\beta$-galactopyranoside (pNP$\beta$-Gal) as the substrate. The reaction was performed in the presence of either free or immobilized enzyme (7 $\left.\mu \mathrm{g} \cdot \mathrm{ml}^{-1}\right)$ in phosphate-citrate buffer (pH=6; $20 \mathrm{mM}$ ) containing 3.3 $\mathrm{mM}$ pNP- $\beta$-Gal (a total volume of $300 \mu \mathrm{l}$ ). After 4 min incubation at $50^{\circ} \mathrm{C}$, the reaction was stopped by the addition of $300 \mu \mathrm{l}$ of $\mathrm{Na}_{2} \mathrm{CO}_{3}(1 \mathrm{M})$. The samples were then centrifuged at $20,000 \mathrm{~g}$ for $1 \mathrm{~min}$ prior to measuring the absorbance. A Thermo Scientific ${ }^{\mathrm{TM}}$ NanoDrop $^{\mathrm{TM}}$ spectrophotometer was used to record the absorbance at $420 \mathrm{~nm}$ and the concentration of the released pNP was then determined using a pNP standard calibration curve. One unit (U) of $\beta$-galactosidase hydrolytic activity is defined as the amount of enzyme releasing $1 \mu \mathrm{mol}$ pNP per minute under the assay conditions.

\section{Biotransformation of lactose via transgalactosylation reaction}

To assay the transgalactosylation activity of the free and immobilized enzymes, transgalactosylation of GlcNAc by lactose was carried out to form LacNAc. The transgalactosylation reaction was performed in a mixture with a total volume of $1,500 \mu \mathrm{l}$ containing $50 \mathrm{mM}$ lactose and $500 \mathrm{mM} \mathrm{GlcNAc}$ in phosphate-citrate buffer (pH=6), giving an acceptor to donor ratio of 10 to favor galactosidase-catalyzed transgalactosylation. ${ }^{1}$ The reaction was carried out at $50^{\circ} \mathrm{C}$ in a thermomixer (Eppendorf) for up to $150 \mathrm{~min}$. An initial concentration of $0.14 \mathrm{U}^{\mathrm{ml}}{ }^{-1}$ of both the free enzyme and immobilized enzyme was used to instigate the reaction. In addition, a concentration of $0.63 \mathrm{U}^{\mathrm{ml}}{ }^{-1}$ of the free enzyme which 
corresponds to the same initial transgalactosylation activity of the immobilized enzyme was used for further comparison. The reaction was stopped at specified time points by the transfer of a $20 \mu \mathrm{l}$ sample withdrawn from the reaction solution to a cold mixture of $80 \mu \mathrm{l}$ methanol and $20 \mu \mathrm{l}$ chloroform. A total of $300 \mu \mathrm{l}$ water (Millipore Elix) was added to this mixture followed by centrifugation at 20,000g for $1 \mathrm{~min}$ to precipitate the enzyme before HPLC analysis. The supernatant was collected and kept at $-20^{\circ} \mathrm{C}$. One unit of $\beta$-galactosidase transgalactosylation activity is defined as the amount of enzyme catalyzing the formation of $1 \mu$ mol LacNAc per minute under the assay conditions.

An immobilized enzyme sample was also incubated under the same conditions without GlcNAc and lactose substrates and after $150 \mathrm{~min}$, the supernatant was separated by centrifugation at 20,000g for $1 \mathrm{~min}$ and then used for the detection of any enzyme leakage using both the UV absorption at $280 \mathrm{~nm}$ and the activity assay.

We have recently demonstrated that the addition of $100 \mathrm{mM}$ of divalent cations, including calcium and magnesium, can result in the formation of $\beta$-galactosidase aggregates 2. For further investigation of the effect of these cations on the immobilized enzyme, transgalactosylation reactions were also performed in the presence of $100 \mathrm{mM} \mathrm{CaCl}_{2}$ or $\mathrm{MgCl}_{2}$ under the same reaction conditions $\left(50^{\circ} \mathrm{C}\right.$ for up to $\left.150 \mathrm{~min}\right)$.

The initial transgalactosylation and hydrolysis rates were calculated by determining the production rate of LacNAc and galactose within the linear product formation range (after 10 min of the reaction), where the secondary hydrolysis of the product is negligible. The initial galactose formation rate is regarded as the initial hydrolysis rate because only galactose is released when water acts as the acceptor. ${ }^{3-4}$ 


\section{Determination of immobilization efficiency, activity retention and performance index}

The protein immobilization efficiency $\left(\frac{E_{\text {adsorbed }}}{E_{\text {total }}}\right)$ is defined as the moles of the enzyme adsorbed onto the support (Eadsorbed) per moles of enzyme provided (Etotal). This efficiency was determined by measuring the difference between the enzyme concentration in the initial enzyme solution and the supernatant and washings using UV absorption at $280 \mathrm{~nm}$ (Thermo Scientific $^{\mathrm{TM}}$ NanoDrop $^{\mathrm{TM}}$ spectrophotometer) with the molecular weight and the molar extinction coefficient at $280 \mathrm{~nm}$ for the $\beta$-galactosidase equal to $192,359 \mathrm{Da}$ and $302,190 \mathrm{M}^{-}$ ${ }^{1} . \mathrm{cm}^{-1}$, respectively. The free enzyme activity was also measured in the supernatant and washings.

The activity retention after immobilization was determined as the specific activity of the immobilized enzyme (U.mg-1 enzyme) to that of the free enzyme, i.e.

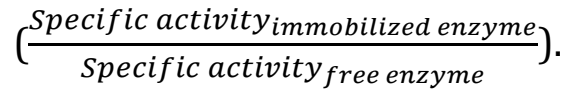

The performance index was determined by calculating the specific productivity (or the biocatalytic productivity rate) as the amount of LacNAc formed per amount of enzyme and reaction time $\left(\frac{\mu \text { mole LacNAc }}{\text { Enzyme amount }(\text { mg }) \cdot \text { Reaction time }}\right) \cdot{ }^{5}$

\section{HPLC analysis}

An Agilent 1200 series High Performance Liquid Chromatography (HPLC) equipped with an Agilent 1290 Infinity II Evaporative Light Scattering Detector (ELSD) and an Agilent Diode Array Detector (DAD) was used to quantify the sugar concentration using an NH2P504E amino column (Asahipak, Japan), which was isocratically eluted at $30{ }^{\circ} \mathrm{C}$ with $75 \%$ acetonitrile/water solution at a flow rate of $1.0 \mathrm{ml}^{\mathrm{min}}{ }^{-1}$. The formation of $\mathrm{N}$-acetyl 
saccharides (UV chromophores) was monitored at $210 \mathrm{~nm}$ using the DAD and the ELSD nebulizer and evaporator temperatures were set at $60^{\circ} \mathrm{C}$ and $50{ }^{\circ} \mathrm{C}$, respectively, with a nitrogen gas flow of 1.6 standard liter per minute (SLM).

\section{Thermal stability test}

The thermal stability of the immobilized and free enzymes was determined by incubating the same initial amounts $\left(0.14 \mathrm{U}^{\mathrm{ml}}{ }^{-1}\right)$ at $55^{\circ} \mathrm{C}$ to $70^{\circ} \mathrm{C}$ in the thermomixer for up to $180 \mathrm{~min}$. At specific time points, aliquots were taken and immediately cooled on ice and the residual activity was measured using the method previously described. The natural logarithm of the residual activity $(\ln (\mathrm{A} / \mathrm{A} 0))$ versus time $(\mathrm{t})$ was fitted to a first order model by which the deactivation constant $\left(\mathrm{k}_{\mathrm{D}}\right)$ was calculated. The half-time $\left(\mathrm{t}_{1 / 2}\right)$, i.e. the incubation time at which $50 \%$ of the initial activity is lost, and the activation energy of the thermal inactivation $\left(E_{a}\right)$ (based on the Arrhenius equation) can be calculated using the following equations:6-7

$$
\begin{gathered}
\ln \left(\frac{A}{A_{0}}\right)=-k_{D} t \\
t_{1 / 2}=\frac{0.693}{k_{D}} \\
\ln \left(k_{D}\right)=-\frac{E_{a}}{R}\left(\frac{1}{T}\right)+\ln (F)
\end{gathered}
$$

Where $\mathrm{F}$ denotes the pre-exponential factor. Using the calculated values for $\mathrm{E}_{\mathrm{a}}$ and $\mathrm{k}_{\mathrm{D}}$, the other thermodynamic parameters, enthalpy $(\Delta \mathrm{H})$, entropy $(\Delta \mathrm{S})$ and Gibbs free energy $(\Delta \mathrm{G})$, are calculated at a given temperature as follows: 


$$
\begin{gathered}
\Delta H=E_{a}-R T \\
\Delta G=-R T \ln \left(\frac{k_{D} h}{k_{B} T}\right) \\
\Delta S=\frac{\Delta H-\Delta G}{T}
\end{gathered}
$$

where $\mathrm{R}, \mathrm{T}, \mathrm{h}$ and $\mathrm{k}_{\mathrm{B}}$ indicate the gas constant $\left(8.314 \mathrm{~J} \mathrm{~mol}^{-1} \mathrm{~K}^{-1}\right)$, absolute temperature $(\mathrm{K})$, Planck's constant $\left(6.626 \times 10^{-34} \mathrm{Js}\right)$ and Boltzmann's constant $\left(1.38 \times 10^{-23} \mathrm{~J} \mathrm{~K}^{-1}\right)$, respectively.

\section{Characterization methods: ATR-FTIR analysis, zeta potential measurement, thermogravimetric analysis and digital microscopy}

An attenuated total reflectance Fourier transform infrared (ATR-FTIR) spectrometer (Bruker) was used to analyze the structural changes in the enzyme before and after immobilization. The number of scans, minimum resolution and wavelength range were set to $100,4 \mathrm{~cm}^{-1}$ and $800-4000 \mathrm{~cm}^{-1}$. A Zetasizer (Nano ZS; Malvern Instruments, Malvern, UK) was used to determine the zeta-potential of particles after the deposition of each layer. Thermogravimetric Analysis (TGA) was conducted on a TGA 209 F1 Libra ${ }^{\circledR}$ (Netzsch, Australia) to measure the change in the mass of immobilized enzyme with temperature from $30{ }^{\circ} \mathrm{C}$ to $800{ }^{\circ} \mathrm{C}$ at a heating rate of $10^{\circ} \mathrm{C} \mathrm{min}^{-1}$. A Hirox RH-2000 2D/3D digital microscope was used to create images of the immobilized enzyme support.

\section{Determination of reusability of immobilized $\beta$-galactosidase}

The immobilized $\beta$-galactosidase was re-used in successive reaction runs under the same conditions described for transgalactosylation. To this end, after each 150 min reaction 
at $50{ }^{\circ} \mathrm{C}$, the immobilized enzyme was separated from the supernatant by centrifugation at 20,000g for $1 \mathrm{~min}$. The supernatant was collected for HPLC analysis and the immobilized enzyme was washed four times using Tris buffer $(\mathrm{pH}=7.2)$ to remove any remaining substrate or product impurity before the next reaction run.

\section{Molecular analysis}

The crystal structure of $\beta$-galactosidase derived from Bacillus circulans (PBD code: 4ypj) was used to locate the available surface amine groups of the enzyme which may react with glutaraldehyde during the cross-linking. Glutaraldehyde is able to specifically react with the amine group of the side chains of lysine, cysteine, histidine and tyrosine. ${ }^{8}$ The PSIVER server was employed to predict enzyme-enzyme interaction sites using a Naïve Bayes classifier (NBC) and a kernel density estimation method (KDE). ${ }^{9}$ The electrostatic surface charge distribution of the enzyme at $\mathrm{pH}=6$ was also predicted by the method described in. ${ }^{2}$ The catalytic pocket region on the enzyme was also predicted by PrankWeb server. ${ }^{10-11}$ The predicted structures were visualized and processed in UCSF Chimera software.

\section{Economic analysis model}

The net present value (NPV) is used to investigate the effect of immobilization on the economic profitability of a large-scale process. Larger positive values of NPV are indicative of a more profitable process:

$$
N P V=\sum_{m=0}^{n} \frac{(\text { After tax cash flow })_{m}}{(1+i)^{m}}=\sum_{m=0}^{n} \frac{\left\{\left[R-\left(\operatorname{COM}_{D E}+D+C_{E} \frac{N_{T}}{N_{U}}\right)\right](1-t)+D\right\}_{m}}{(1+i)^{m}}
$$




$$
D=\frac{F C I-\text { Salvage value }}{\text { Useful life span }}
$$

where $\mathrm{n}$ and i denote the project lifetime and discount rate. $\mathrm{FCI}, \mathrm{COM}_{D E}, \mathrm{R}, \mathrm{D}$ and $\mathrm{t}$ are the fixed capital investments, manufacturing costs (excluding depreciation and enzyme cost), revenues, depreciation and taxation rate, respectively. $\mathrm{C}_{\mathrm{E}}, \mathrm{N}_{\mathrm{T}}$ and $\mathrm{N}_{\mathrm{U}}$ show the enzyme cost per batch, total number of batches per year and the number of reuse cycles, respectively. The ratio of $\frac{N_{T}}{N_{U}}$ was rounded upwards to the nearest integer.

For estimation of the plant costs and revenues needed to calculate the NPV, a simulation of a large-scale LacNAc manufacturing operation was used, as detailed in our earlier publication. ${ }^{12}$ Briefly, a design based selective crystallization was selected and the costs were calculated for the same substrate basis (20 tons of lactose per year) when the immobilized enzyme or free enzyme was used. The revenue (R) is a function of the production yield, losses during the downstream processing and the product selling price. Based on the selling price ranges we have previously estimated, ${ }^{12}$ a sale price of $\$ 10$ per gram of LacNAc was chosen in all cases. To estimate the cost of the immobilized enzyme preparation, we used SuperPro Designer software, as shown in Figure S1. The prices indicated in Table S3 were used and the same concentrations and experimental conditions described in Materials and Methods (see the main manuscript) were considered.

Based on these simulations, a comparison between the sustainability of processes with the use of free enzyme and immobilized enzyme (with eight reuse cycles) was performed. To this end, the quantity of different parameters per kg of product (LacNAc), including waste 
generation, total chemical oxygen demand (COD), raw materials, Cleaning-In-Place (CIP) solutions and water/electricity/steam/chilled water consumption were calculated.

\section{Kinetic model}

In our previous work ${ }^{2}$ we developed the following kinetic model specifically formulated to describe the multi-pathway reactions including transgalactosylation and hydrolysis involved in the conversion of lactose to LacNAc:

\section{Reaction mechanism:}

$$
\begin{gathered}
E+L \stackrel{k_{1}}{\rightarrow} E G a l+G l u \\
E G a l \stackrel{k_{2}}{\rightarrow} E+G a l \\
E G a l+G l c N A c \stackrel{k_{3}}{\rightleftharpoons} E+\text { LacNAc } \\
k_{-3} \\
\text { EGal }+ \text { GlcNAc } \stackrel{k_{4}}{\rightarrow} E+\text { Allo }- \text { LacNAc } \\
E \stackrel{k_{5}}{\rightarrow} E^{\prime}
\end{gathered}
$$


Time-dependent differential kinetic equations:

$$
\begin{gathered}
\frac{d C_{E}}{d t}=-k_{1} C_{E} C_{L}+\frac{k_{3}}{R_{2}} C_{E G a l}+\left(k_{3}+\frac{k_{3}}{R_{4}}\right) C_{E G a l} C_{G l c N A c}-\frac{k_{3}}{R_{-3}} C_{E} C_{L a c N A c}-k_{5} C_{E} \\
\frac{d C_{L}}{d t}=-k_{1} C_{E} C_{L} \\
\frac{d C_{E G a l}}{d t}=k_{1} C_{E} C_{L}-\frac{k_{3}}{R_{2}} C_{E G a l}-\left(k_{3}+\frac{k_{3}}{R_{4}}\right) C_{E G a l} C_{G l c N A c}+\frac{k_{3}}{R_{-3}} C_{E} C_{L a c N A c} \\
\frac{d C_{G l u}}{d t}=k_{1} C_{E} C_{L} \\
\frac{d C_{G a l}}{d t}=\frac{k_{3}}{R_{2}} C_{E G a l} \\
\frac{d C_{G l c N A c}}{d t}=-\left(k_{3}+\frac{k_{3}}{R_{4}}\right) C_{E G a l} C_{G l c N A c}+\frac{k_{3}}{R_{-3}} C_{E} C_{L a c N A c} \\
\frac{d C_{L a c N A c}}{d t}=k_{3} C_{E G a l} C_{G l c N A c}-\frac{k_{3}}{R_{-3}} C_{E} C_{L a c N A c} \\
d t
\end{gathered}
$$

Equation

S1

Equation

S2

Equation

S3

Equation

S4

Equation

S5

Equation

S6

Equation

S7

Equation

S8

Equation

S9

$\frac{d C_{E^{\prime}}}{d t}=k_{5} C_{E}$

$R_{2}=\frac{k_{3}}{k_{2}}$

$$
R_{4}=\frac{k_{3}}{k_{4}}
$$

Equation

S10

Equation

S11 


$$
R_{-3}=\frac{k_{3}}{k_{-3}}
$$

Equation

where E, L, EGal, Glu, Gal, and E' denote the enzyme, lactose, enzyme-galactosyl intermediate, glucose, galactose and inactivated enzyme.

A genetic algorithm (GA) was performed to estimate the rate constants $\left(\mathrm{k}_{\mathrm{i}}\right)$ by minimizing an objective function, defined as the summation of the absolute differences between the experimental $\left(C_{i}^{\text {experiment }}\right)$ and modeled $\left(C_{i}^{\text {model }}\right)$ concentrations when the immobilized enzyme or free enzyme are used (Figure S2). The GA and relevant codes were prepared in MATLAB R2017b. The GA was initiated with a large population size of 150 to ensure the global optimization and GlobalSearch algorithm was also carried out using the initial values obtained from the GA outputs to further check the global minimization. More details can be found in Karimi Alavijeh et al. ${ }^{2}$ The code was repeated fifty times and the results used to calculate statistical data, including confidence intervals, standard errors and t-score statistics. The coefficient of determination $\left(\mathrm{R}^{2}\right)$, root mean square deviation (RMSD) and mean absolute deviation (MAD) were calculated using the following equations to evaluate the model accuracy:

$$
\begin{gathered}
S S_{T}=\sum_{i}\left(C_{i}^{\text {experiment }}-\bar{C}\right)^{2} \\
S S_{R}=\sum_{i}\left(C_{i}^{\text {experiment }}-C_{i}^{\text {model }}\right)^{2} \\
R^{2}=1-\frac{S S_{R}}{S S_{T}}
\end{gathered}
$$




$$
R M S D=\sqrt{\frac{\sum_{i}\left(C_{i}^{\text {experiment }}-C_{i}^{\text {model }}\right)^{2}}{n}}
$$

$$
M A D=\frac{\sum_{i}\left|C_{i}^{\text {experiment }}-\bar{C}\right|}{n}
$$

where $\mathrm{SS}_{\mathrm{T}}$ and $\mathrm{SS}_{\mathrm{R}}$ are the total and residual sum of squares and $C^{\text {experiment }}, \bar{C}, C^{\text {model }}$ and n denote the experimental concentrations, the mean of the experimental concentrations, the modeled concentrations and total number of data, respectively. 


\section{Tables}

Table S1. Estimated rate constants for the free and immobilized enzyme.

\begin{tabular}{lcc}
\hline Constant & Free enzyme & Immobilized enzyme \\
\hline $\mathrm{k}_{1} \times 10^{-3}\left(\mathrm{M}^{-1} \mathrm{~min}^{-1}\right)$ & $57.8 \pm 0.7$ & $36.7 \pm 0.6$ \\
$\mathrm{k}_{2} \times 10^{-5}\left(\mathrm{~min}^{-1}\right)$ & $21 \pm 2$ & $1.4 \pm 0.2$ \\
$\mathrm{k}_{3} \times 10^{-5}\left(\mathrm{M}^{-1} \mathrm{~min}^{-1}\right)$ & $295 \pm 21$ & $28.5 \pm 5$ \\
$\mathrm{k}_{4} \times 10^{-5}\left(\mathrm{M}^{-1} \mathrm{~min}^{-1}\right)$ & $9.5 \pm 0.8$ & $2 \pm 0.4$ \\
$\mathrm{k}-3 \times 10^{-4}\left(\mathrm{M}^{-1} \mathrm{~min}^{-1}\right)$ & $23 \pm 3$ & $2.2 \pm 0.5$ \\
$\mathrm{k}_{5} \times 10^{3}\left(\mathrm{~min}^{-1}\right)$ & $4.1 \pm 1$ & 0 \\
\hline
\end{tabular}

Table S2. Assumptions and economic parameters used for economic evaluations.

\begin{tabular}{|c|c|c|}
\hline Item & \multicolumn{2}{|c|}{ Description/Value } \\
\hline Currency & \multicolumn{2}{|l|}{ US Dollar } \\
\hline Project lifetime & \multicolumn{2}{|l|}{25 years } \\
\hline Year of analysis & \multicolumn{2}{|l|}{2017} \\
\hline Annual operating time & \multicolumn{2}{|c|}{330 days ( 24 hours per day) } \\
\hline Construction period & \multicolumn{2}{|l|}{2 years } \\
\hline Startup period & \multicolumn{2}{|l|}{6 months } \\
\hline Discount rate & \multicolumn{2}{|l|}{$7 \%$} \\
\hline Taxation rate & \multicolumn{2}{|l|}{$35 \%$} \\
\hline Depreciation & \multicolumn{2}{|c|}{ Straight line method over 15 years } \\
\hline Salvage value & \multicolumn{2}{|c|}{$5 \%$ of fixed capital } \\
\hline Startup and validation & \multicolumn{2}{|c|}{$5 \%$ of fixed capital } \\
\hline LacNAc selling price & \multicolumn{2}{|c|}{$\$ 10$ per gram } \\
\hline \multicolumn{3}{|l|}{ Cost estimations and product quantity } \\
\hline \multirow[t]{2}{*}{ Downstream processing 1} & \multicolumn{2}{|c|}{ Selective crystallization } \\
\hline & $\begin{array}{l}\text { Immobilized } \\
\text { enzyme }\end{array}$ & $\begin{array}{l}\text { Free } \\
\text { enzyme }\end{array}$ \\
\hline Lactose $\left(\mathrm{t} \mathrm{yr}^{-1}\right)$ & 20 & 20 \\
\hline LacNAc production ( $\left.\mathrm{t} \mathrm{yr}^{-1}\right)$ & 8.5 & 6.3 \\
\hline Number of batches per year & 162 & 168 \\
\hline $\begin{array}{l}\text { Cost of manufacturing excluding depreciation }\left(10^{6} \$ \mathrm{yr}^{-}\right. \\
\text {1) }\end{array}$ & 8 & 7 \\
\hline Fixed capital investment $\left(10^{6} \$\right)$ & 28 & 26 \\
\hline Working capital $\left(10^{3} \$\right)$ & 410 & 395 \\
\hline Net present value (NPV) $\left(10^{6} \$\right)$ & $463^{2}$ & 333 \\
\hline
\end{tabular}


Table S3. Raw materials and utility costs.

\begin{tabular}{lccc}
\hline Item & Price & Unit & Ref. \\
\hline Lactose & 0.83 & $\$ \mathrm{~kg}^{-1}$ & 13 \\
Water & 0.34 & $\$ \mathrm{t}^{-1}$ & 14 \\
Methanol & 0.42 & $\$ \mathrm{~kg}^{-1}$ & 15 \\
GlcNAc & 20 & $\$ \mathrm{~kg}^{-1}$ & 16 \\
PAH & 39 & $\$ \mathrm{~kg}^{-1}$ & UChem Co., Ltd. \\
PSS & 30 & $\$ \mathrm{~kg}^{-1}$ & Afine Chemicals Limited \\
Sipernat 50S & 8 & $\$ \mathrm{~kg}^{-1}$ & Evonik Resource Efficiency \\
Glutaraldehyde & 55 & $\$ \mathrm{~kg}^{-1}$ & Hebei Chisure Biotechnology Co. \\
Lactazyme-B & 500 & $\$ \mathrm{~kg}^{-1}$ & GenoFocus Co., Ltd. \\
Conventional wastewater & 0.55 & $\$ \mathrm{~m}^{-3}$ & 17 \\
treatment & 0.04 & $\$ \mathrm{~kg}^{-1}$ & 18 \\
Solid waste disposal & & $\$ \mathrm{kWh}^{-}$ & 19 \\
Electricity & 0.069 & 1 & 20 \\
Steam & 3.44 & $\$ \mathrm{t}^{-1}$ & 14 \\
Chilled water & 0.42 & $\$ \mathrm{t}^{-1}$ & 21 \\
Membrane & 44 & $\$ \mathrm{~m}^{-2}$ & \\
\hline
\end{tabular}




\section{Figures}
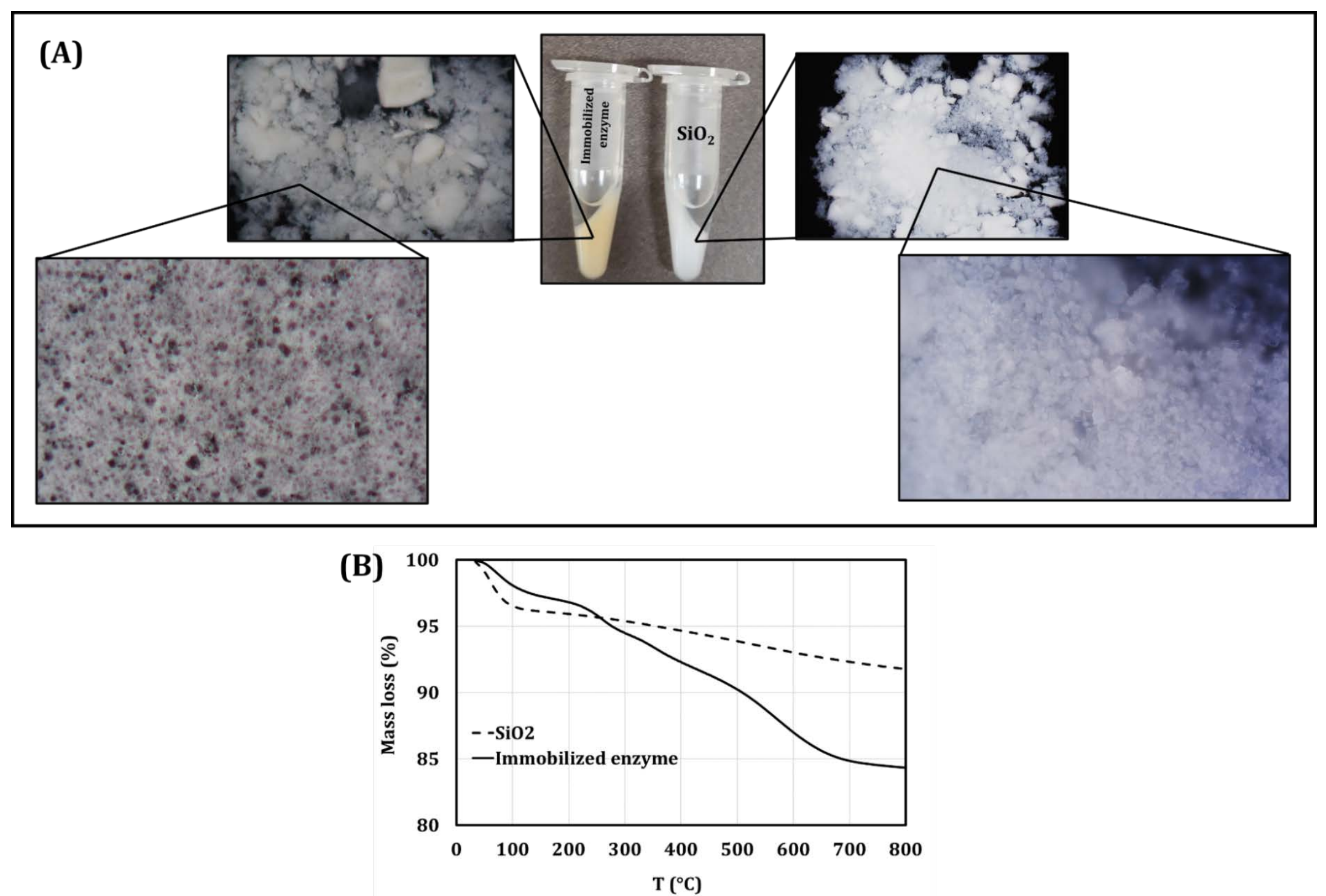

Figure S1. (A) Changes in the color of silica particles after enzyme immobilization (microscopy images created using a Hirox digital microscope). Wang and Caruso ${ }^{22}$ observed similar variations in the color of silica particles after enzyme immobilization. (B) Thermogravimetric Analysis (TGA) of silica before and after enzyme immobilization, illustrating mass loss as a function of heating. 

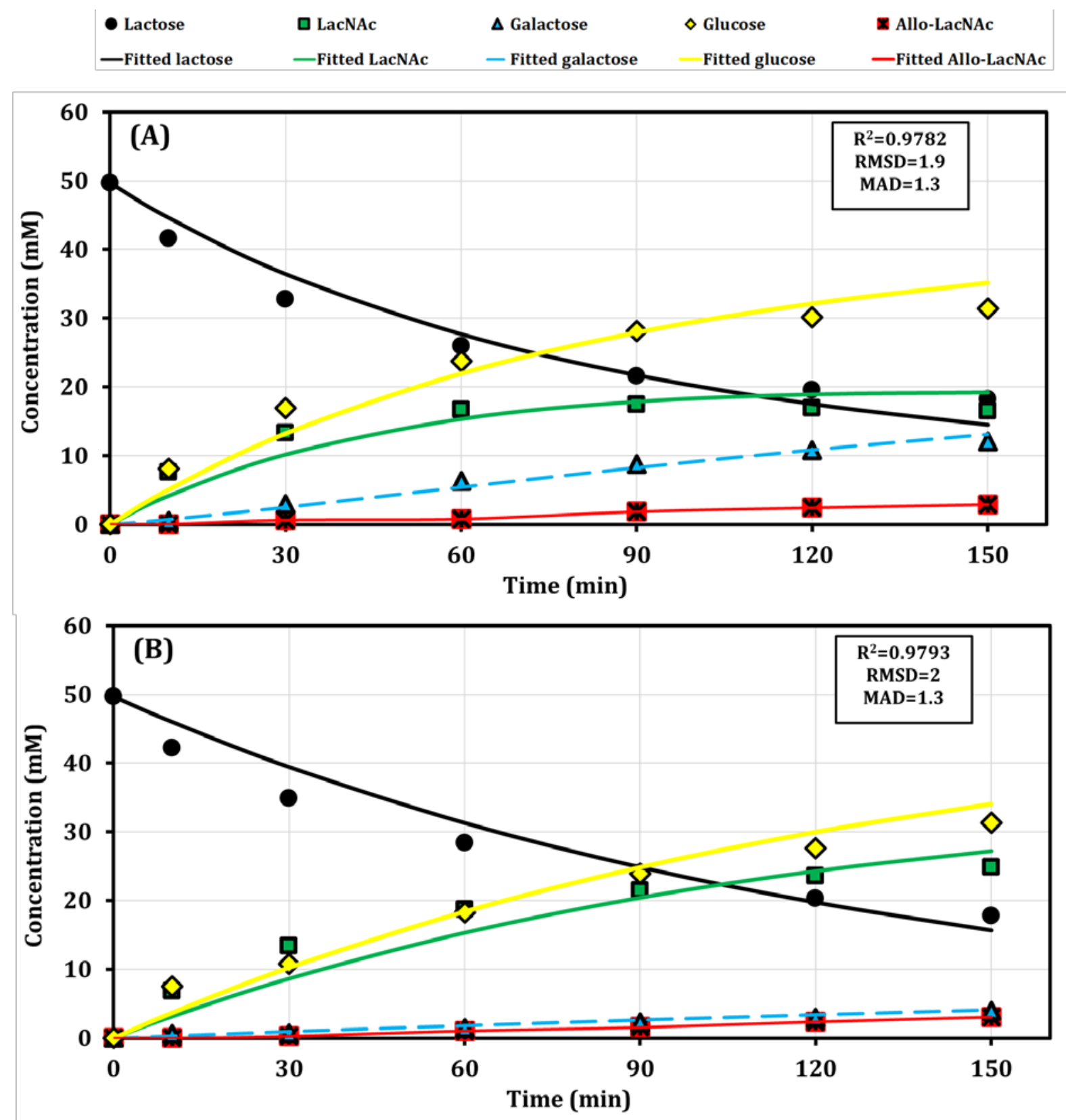

Figure S2. Calculated time-course variations in sugar concentrations based on the kinetic model versus experimental results when (A) the free enzyme and (B) the immobilized enzyme with the same initial transgalactosylation activities were applied in the reaction. 

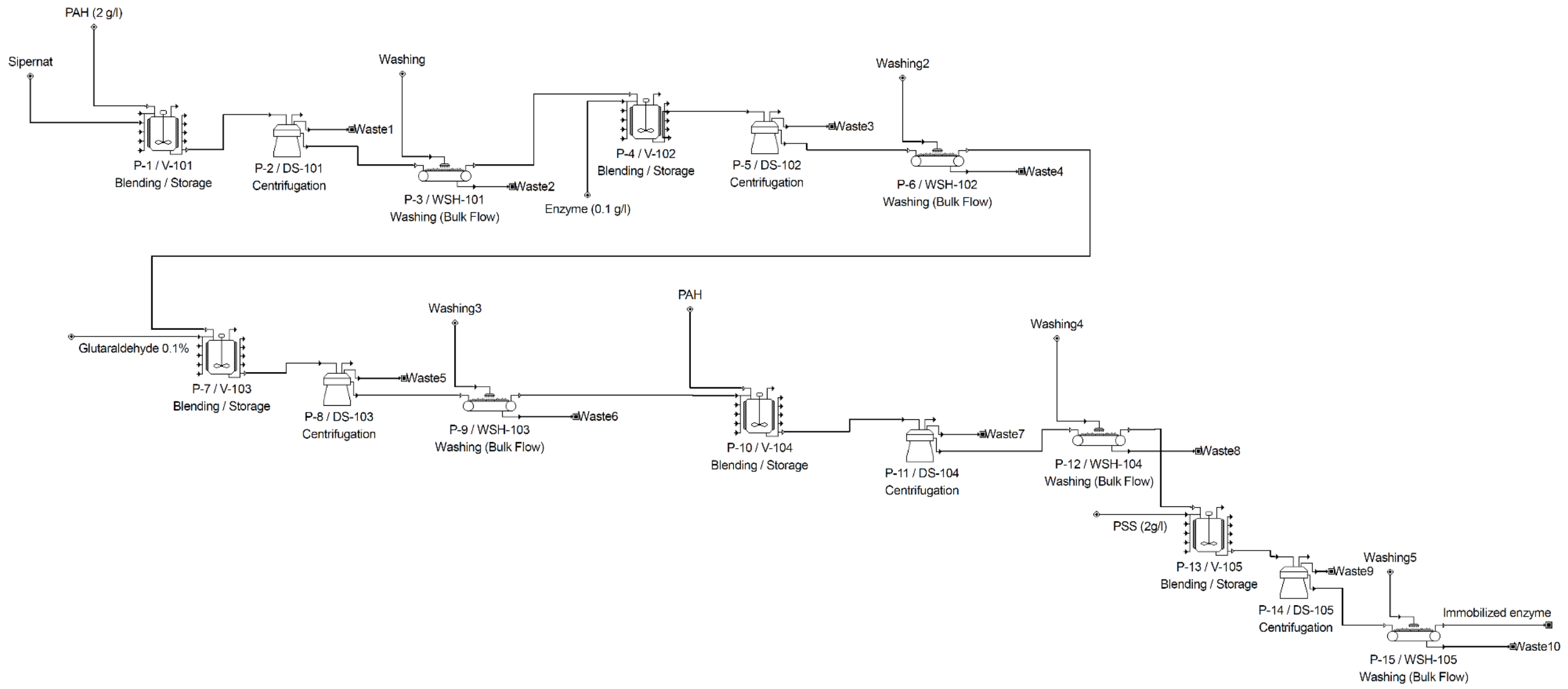

Figure S3. A schematic representation of the unit operations for immobilizing the enzyme using the cross-linked layer-by-layer method used in this study. 


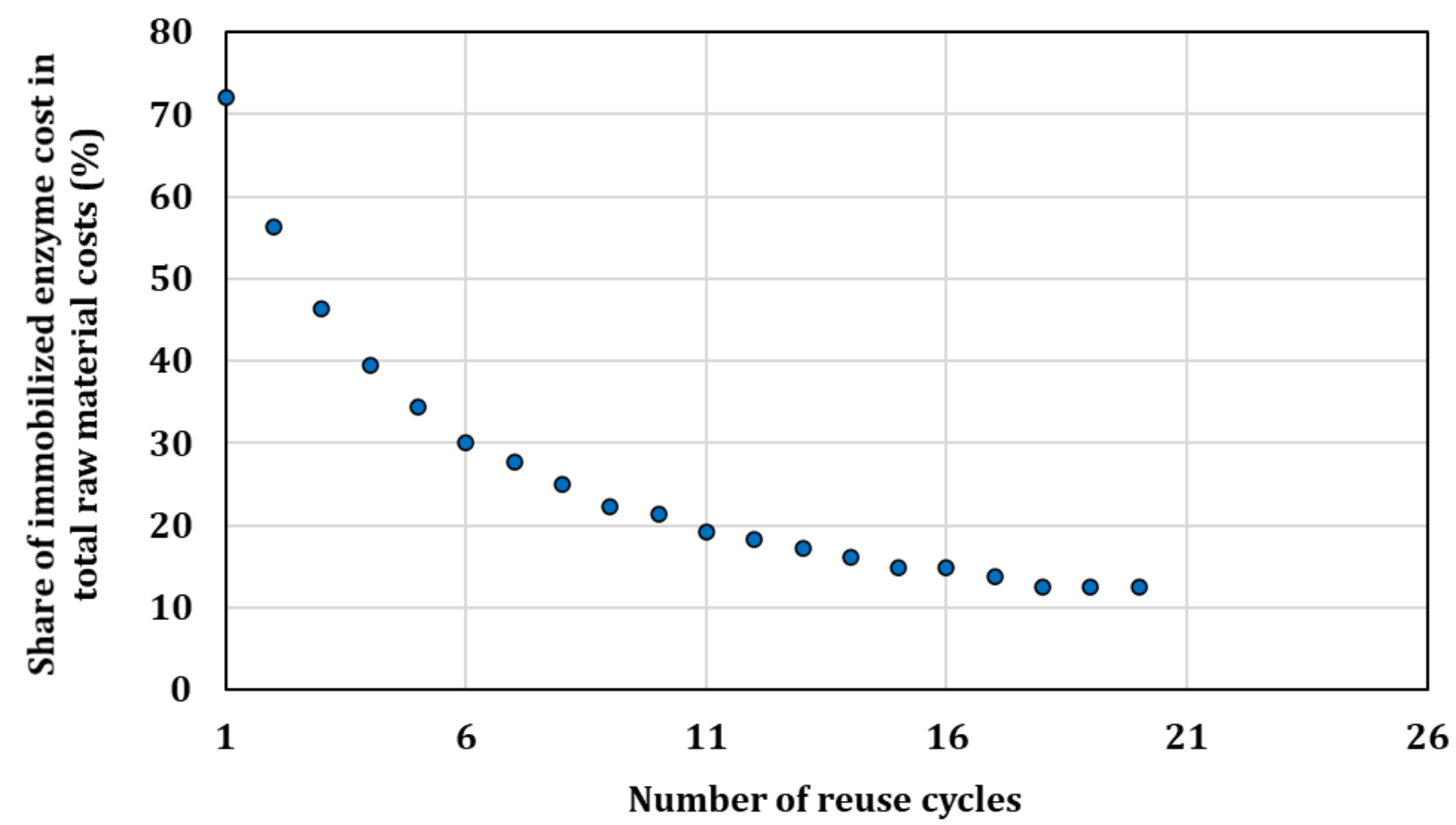

Figure S4. Changes in the share of the total raw material cost that arises from enzyme immobilization versus the number of reuse cycles. 


\section{References}

(1) Zeuner, B.; Nyffenegger, C.; Mikkelsen, J. D.; Meyer, A. S., Thermostable $\beta$ galactosidases for the synthesis of human milk oligosaccharides. New Biotechnol. 2016, 33 (3), 355-360, DOI: 10.1016/j.nbt.2016.01.003.

(2) Karimi Alavijeh, M.; Meyer, A. S.; Gras, S.; Kentish, S. E., The role of cations in regulating reaction pathways driven by Bacillus circulans $\beta$-galactosidase. Chem. Eng. J. 2020, 395, 125067, DOI: 10.1016/j.cej.2020.125067.

(3) Suárez, S.; Guerrero, C.; Vera, C.; Illanes, A., Effect of particle size and enzyme load on the simultaneous reactions of lactose hydrolysis and transgalactosylation with glyoxylagarose immobilized $\beta$-galactosidase from Aspergillus oryzae. Process Biochem. 2018, 73, 56-64, DOI: 10.1016/j.procbio.2018.08.016.

(4) Gosling, A.; Stevens, G. W.; Barber, A. R.; Kentish, S. E.; Gras, S. L., Effect of the Substrate Concentration and Water Activity on the Yield and Rate of the Transfer Reaction of $\beta$ Galactosidase from Bacillus circulans. J. Agric. Food Chem. 2011, 59 (7), 3366-3372, DOI: 10.1021/jf104397w.

(5) Marpani, F.; Sárossy, Z.; Pinelo, M.; Meyer, A. S., Kinetics based reaction optimization of enzyme catalyzed reduction of formaldehyde to methanol with synchronous cofactor regeneration. Biotechnol. Bioeng. 2017, 114 (12), 2762-2770, DOI: 10.1002/bit.26405.

(6) Sillu, D.; Agnihotri, S., Cellulase Immobilization onto Magnetic Halloysite Nanotubes: Enhanced Enzyme Activity and Stability with High Cellulose Saccharification. ACS Sustainable Chem. Eng. 2020, 8 (2), 900-913, DOI: 10.1021/acssuschemeng.9b05400.

(7) Puente-Santiago, A. R.; Rodríguez-Padrón, D.; Quan, X.; Muñoz Batista, M. J.; Martins, L. O.; Verma, S.; Varma, R. S.; Zhou, J.; Luque, R., Unprecedented Wiring Efficiency of Sulfonated Graphitic Carbon Nitride Materials: Toward High-Performance Amperometric Recombinant CotA Laccase Biosensors. ACS Sustainable Chem. Eng. 2019, 7 (1), 1474-1484, DOI: $10.1021 /$ acssuschemeng.8b05107.

(8) Raquez, J. M.; Deléglise, M.; Lacrampe, M. F.; Krawczak, P., Thermosetting (bio)materials derived from renewable resources: A critical review. Prog. Polym. Sci. 2010, 35 (4), 487-509, DOI: 10.1016/j.progpolymsci.2010.01.001.

(9) Murakami, Y.; Mizuguchi, K., Applying the Naïve Bayes classifier with kernel density estimation to the prediction of protein-protein interaction sites. Bioinformatics (Oxford, England) 2010, 26 (15), 1841-8, DOI: 10.1093/bioinformatics/btq302.

(10) Jendele, L.; Krivak, R.; Skoda, P.; Novotny, M.; Hoksza, D., PrankWeb: a web server for ligand binding site prediction and visualization. Nucleic Acids Res. 2019, 47 (W1), W345W349, DOI: $10.1093 /$ nar/gkz424. 
(11) Krivák, R.; Hoksza, D., P2Rank: machine learning based tool for rapid and accurate prediction of ligand binding sites from protein structure. J. Cheminformatics 2018, 10 (1), 39, DOI: $10.1186 / \mathrm{s} 13321-018-0285-8$.

(12) Karimi Alavijeh, M.; Meyer, A. S.; Gras, S. L.; Kentish, S. E., Simulation and economic assessment of large-scale enzymatic N-acetyllactosamine manufacture. Biochem. Eng. J. 2020, 154, 107459, DOI: 10.1016/j.bej.2019.107459.

(13) U.S. Dairy Export Council Lactose historical pricing. www.usdec.org/research-anddata/market-information/prices.

(14) Asadi, N.; Karimi Alavijeh, M.; Zilouei, H., Biological hydrogen production by Enterobacter aerogenes: Structural analysis of treated rice straw and effect of substrate concentration. Int. J. Hydrogen Energ. 2018, 43 (18), 8718-8728, DOI: 10.1016/j.ijhydene.2018.03.137.

(15) Methanex Methanol prices for North America, Europe and Asia.; Methanex Corporation: 2018.

(16) Awell Ingredients Factory Supply N-Acetyl Glucosamine. www.awelling.com.

(17) Chen, G. Q.; Talebi, S.; Gras, S. L.; Weeks, M.; Kentish, S. E., A review of salty waste stream management in the Australian dairy industry. J. Environ. Manage. 2018, 224, 406413, DOI: 10.1016/j.jenvman.2018.07.056.

(18) Turton, R.; Bailie, R. C.; Whiting, W. B.; Shaeiwitz, J. A., Estimation of Manufacturing Costs. In Analysis, Synthesis and Design of Chemical Processes, Turton, R.; Bailie, R. C.; Whiting, W. B.; Shaeiwitz, J. A.; Bhattacharyya, D., Eds. Pearson Education: 2012; pp 242-274.

(19) EIA Electric Power Monthly; Energy Information Administration: 2018.

(20) Shafiei, M.; Kabir, M. M.; Zilouei, H.; Sárvári Horváth, I.; Karimi, K., Techno-economical study of biogas production improved by steam explosion pretreatment. Bioresour. Technol. 2013, 148, 53-60, DOI: 10.1016/j.biortech.2013.08.111.

(21) Meneses, Y. E.; Flores, R. A., Feasibility, safety, and economic implications of wheyrecovered water in cleaning-in-place systems: A case study on water conservation for the dairy industry. J. Dairy Sci. 216, 99 (5), 3396-3407, DOI: 10.3168/jds.2015-10306.

(22) Wang, Y.; Caruso, F., Mesoporous Silica Spheres as Supports for Enzyme Immobilization and Encapsulation. Chem. Mater. 2005, 17 (5), 953-961, DOI: $10.1021 / \mathrm{cm} 0483137$. 